\title{
Loss of Estrogen Receptor $\alpha$ Signaling Leads to Insulin Resistance and Obesity in Young and Adult Female Mice
}

\author{
Camila Manrique $\mathrm{a}^{\mathrm{a}, \mathrm{b}}$ Guido Lastra $^{\mathrm{a}, \mathrm{b}}$ Javad Habibi ${ }^{\mathrm{a}, \mathrm{b}, \mathrm{d}}$ \\ Irina Mugerfeld ${ }^{a, b, d}$ Mona Garro ${ }^{a, b, d}$ James R. Sowers ${ }^{a-d}$ \\ a Diabetes and Cardiovascular Center, and Departments of ${ }^{b}$ Internal Medicine and \\ ${ }^{\mathrm{C}}$ Medical Pharmacology and Physiology, and ${ }^{\mathrm{d}}$ Harry S. Truman Veterans Affair Medical \\ Center, University of Missouri School of Medicine, Columbia, Mo., USA
}

\author{
Key Words \\ Estrogen $\cdot$ Insulin resistance $\cdot$ Skeletal muscle
}

\begin{abstract}
Background/Aims: There are important sex-related differences in the prevalence of obesity, type 2 diabetes mellitus and cardiovascular disease. Indeed, premenopausal women have a lower prevalence of these conditions relative to age-matched men. Estrogen participates in the modulation of insulin sensitivity, energy balance, and body composition. In this paper, we investigated the impact of estrogen signaling through estrogen receptor $\alpha(E R \alpha)$ on systemic insulin sensitivity and insulin signaling in skeletal muscle. Methods: In 14- and 30-week-old female ER $\alpha$ knockout (ER $\alpha K O$ ) mice and age-matched controls, we assessed insulin sensitivity by a euglycemic-hyperinsulinemic clamp and intraperitoneal glucose tolerance testing. Blood pressure was evaluated by tail cuff and telemetry. We studied ex vivo insulin-stimulated glucose uptake in skeletal muscle tissue, as well as insulin metabolic signaling molecule phosphorylation by immunoblotting and oxidative stress by immunostaining for 3-nitrotyrosine. Results: Body weight was higher in ER $\alpha$ KO mice at 14 and 30 weeks of age. At 30 weeks, intraperitoneal glucose tolerance testing and clamp results demonstrated impaired systemic insulin sensitivity in ER $\alpha \mathrm{KO}$ mice. Insulin-stimulated glucose uptake in soleus was lower in ER $\alpha \mathrm{KO}$ mice at both ages. The insulin receptor substrate 1/phosphatidylinositol 3-kinase association and the activa-
\end{abstract}

C.M. and G.L. contributed equally to this paper.

Camila Manrique, MD

D109 Diabetes Center UHC

One Hospital Drive

Columbia, MO 65212 (USA)

Tel. +1 573884 0769, E-Mail manriquec@ @ealth.missouri.edu 


\section{CardioRenal Medicine}

\begin{tabular}{l|l}
\hline \begin{tabular}{l} 
Cardiorenal Med 2012;2:200-210 \\
\hline DOI: 10.1159/000339563
\end{tabular} & $\begin{array}{l}\text { @ } 2012 \text { S. Karger AG, Basel } \\
\text { www.karger.com/crm }\end{array}$ \\
\hline Published online: July 7, 2012 & $\begin{array}{l}\text { Manrique et al.: Loss of Estrogen Receptor a Signaling Leads to Insulin Resistance and } \\
\text { Obesity in Young and Adult Female Mice }\end{array}$
\end{tabular}

tion of protein kinase B were decreased in ER $\alpha$ KO mice, whereas immunostaining for 3-nitrotyrosine was increased. Conclusions: Our data demonstrate a critical age-dependent role for estrogen signaling through $\mathrm{ER} \alpha$ on whole-body insulin sensitivity and insulin metabolic signaling in skeletal muscle tissue. These findings have potential translational implications for the prevention and management of type 2 diabetes mellitus and cardiovascular disease in women, who are at increased risk for these conditions.

Copyright $\odot 2012$ S. Karger AG, Basel

\section{Introduction}

The incidence and prevalence of obesity continues to reach pandemic proportions and is a leading force behind the also worrisome frequency of type 2 diabetes mellitus (DM2) and cardiovascular disease (CVD), causing significant morbidity, mortality and imposing a severe economic burden to health care systems in both industrialized and non-industrialized countries [1]. According to the National Health health care systems in and Nutrition Examination Survey (NHANES), between 1999 and 2010 the overall age-adjusted prevalence of obesity in the USA was $35.8 \%$ in adult men and $35.5 \%$ in adult women [2]. DM2 currently affects more than $8 \%$ of the US population [3] and associated CVD is a leading cause of premature morbidity and mortality.

There are important sex-related differences in the prevalence of obesity, DM2, hypertension and CVD, with premenopausal women at less risk relative to age-matched men [4, 5]. This lower incidence appears to stem from a protective effect of estrogen against obesity, insulin resistance and CVD complications [4, 5]. Indeed, menopause-associated reductions in estrogen are linked to a substantial increase in the incidence of obesity, DM2 and CVDassociated mortality in women [5]. Estrogens are known to be involved in the modulation of insulin sensitivity, energy balance, blood pressure and body composition [4]. In this regard, estrogen modulates appetite, insulin release, glucose transport in skeletal muscle and liver, adipocyte differentiation and vascular tone and structure [6]. Animal and human models of estrogen depletion are characterized by abdominal obesity and insulin resistance. Studies in rodents have demonstrated that ovariectomy results in increased adiposity, which can be reversed by exogenous administration of estrogen and impact insulin sensitivity [4]. Mice lacking aromatase, the enzyme that converts androgens to estrogens, develop obesity related to reduced physical activity and decreased lean body mass [7].

Nonetheless, the impact and the mechanisms that link estrogen receptor (ER) signaling and insulin sensitivity remain to be fully elucidated. The cellular actions of estrogens are mediated by two different types of ERs, ER $\alpha$ and ER $\beta$, and a third membrane-bound G protein coupled receptor (GPR30) has been recently characterized [8]. Available literature suggests that the influence of estrogen on insulin sensitivity is largely mediated by estrogen signaling through ER $\alpha$. Compared to wild type (ER $\alpha \mathrm{Wt}$ ) animals, knockout (KO) of the ER $\alpha$ in mice results in obesity at the expense of white adipose tissue expansion, reduced energy expenditure, insulin resistance and glucose intolerance [9]. On the other hand, ER $\beta$ KO mice have normal glucose tolerance and insulin release relative to Wt mice [10] and it has been suggested that ER $\beta K O$ protects against diet-induced insulin resistance and glucose intolerance [11].

In the current investigation, we have evaluated the impact of signaling through ER $\alpha$ on whole-body and skeletal muscle insulin sensitivity and circadian blood pressures in both young and adult female $\mathrm{ER} \alpha \mathrm{KO}$ mice. Our study provides further evidence for a major role of ER $\alpha$ in skeletal muscle as a determinant of body composition and systemic insulin sensitivity. Our data further contribute to explain the impact of estrogen depletion on the increased risk of obesity, DM2 and CVD in post-menopausal women. 


\section{CardioRenal Medicine}

\begin{tabular}{l|l}
\hline \multicolumn{2}{l}{ Cardiorenal Med 2012;2:200-210 } \\
\hline DOI: $10.1159 / 000339563$ \\
Published online: July 7, 2012 & $\begin{array}{l}\text { @ 2012 S. Karger AG, Basel } \\
\text { www.karger.com/crm }\end{array}$ \\
\hline
\end{tabular}

Manrique et al.: Loss of Estrogen Receptor $\alpha$ Signaling Leads to Insulin Resistance and Obesity in Young and Adult Female Mice

\section{Methods}

Animals

All animal procedures were performed in accordance with the Animal Use and Care Committee at the University of Missouri, Columbia. $\mathrm{ER} \alpha \mathrm{KO}$ mice and littermate controls (ER $\alpha \mathrm{Wt}$ ) were obtained from Jackson Laboratories (Bar Harbor, Me., USA) and from Dr. Dennis Lubahn's breeding colony at the School of Veterinary Medicine of the University of Missouri. Female mice were provided with standard mice chow and water for ad libitum consumption while housed in pairs under a 12-hour/day illumination regimen.

\section{Body Composition}

Body composition was examined by nuclear magnetic resonance spectroscopy.

\section{Blood Pressure Assessment}

Tail Cuff

Acclimation to the mouse holders and tail cuff apparatus was initiated and continued daily 4 days prior to data acquisition using the Kent Coda 8 non-invasive tail cuff blood pressure system. On the day of measurement, the mice were again acclimated to the holders and cuff system for $10 \mathrm{~min}$ prior to collecting data. The instrument is set to collect several dozen measurements in a short time, while the software determines validity of each measurement. Data is reported in excel and valid readings are used to calculate mean values for each mouse (Kent Scientific Corporation, Torrington, Conn., USA).

\section{Telemetry}

Female $\mathrm{ER} \alpha \mathrm{KO}$ and $\mathrm{ER} \alpha \mathrm{Wt}$ mice at 30 weeks of age were anesthetized (2\% isoflurane in a stream of air containing $40 \% \mathrm{O}_{2}$ ) and instrumented with an abdominal aorta catheter attached to a radiotransmitter (Data Sciences International, St. Paul, Minn., USA) as previously described [12]. After a 1-week recovery, mice were monitored in 300-s bins every $15 \mathrm{~min}$ for three 12-hour light and three 12-hour dark cycles (sampling rate $=1,000 \mathrm{~Hz}$ ). Parameters evaluated include systolic blood pressure $(\mathrm{SBP}$ ) and spontaneous cage activity [counts of lateral movement per minute (cpm)].

\section{Assessment of Whole-Body Insulin Sensitivity}

Euglycemic-Hyperinsulinemic Clamp

Female $\mathrm{ER} \alpha \mathrm{KO}$ and $\mathrm{ER} \alpha \mathrm{Wt}$ mice aged 20 weeks underwent euglycemic-hyperinsulinemic clamp ( 2 milliunits $\cdot \mathrm{kg}^{-1} \cdot \mathrm{min}^{-1}$ insulin) at the Vanderbilt University School of Medicine Mouse Metabolic Phenotyping Center as previously described [13]. Five days previous to the study, carotid artery and jugular vein catheters were placed for blood sampling and infusion. The studies were only done in mice which weighed within $10 \%$ of pre-surgical body weight.

Intraperitoneal Glucose Tolerance Test

Intraperitoneal glucose tolerance test (IPGTT) was performed in the cohort of ER $\alpha \mathrm{KO}$ and $\mathrm{ER} \alpha \mathrm{Wt}$ mice aged 14 and 30 weeks maintained at the University of Missouri. After a 5 -hour fast, dextrose $(0.75$ $\mathrm{g} / \mathrm{kg}$ ) was to be injected intraperitoneally and the glucose excursion following injection was monitored over time and compared between cohorts. Blood samples were analyzed for glucose (AlphaTRACK, Abbott, Ill., USA) at time 0 and 15, 30, 45, 60, and $120 \mathrm{~min}$ following the injection. The glycemic excursion after the injection was evaluated as the area under the curve (AUC) as previously described [14].

\section{Glucose Uptake in Skeletal Muscle}

2-Deoxyglucose (2-DOG) transport was measured in soleus muscle from 14- and 30-week-old female mice as previously described [14]. Briefly, isolated whole soleus muscles were placed in pre-incubation buffer containing prepared Krebs-Henseleit buffer (KHB) with $8 \mathrm{mM}$ glucose and $32 \mathrm{~mm}$ mannitol, with or without $5 \mathrm{mU} / \mathrm{ml}$ human insulin (Novo Nordisk Inc., Bagsvaerd, Denmark), for $45 \mathrm{~min}$. The soleus was then transferred to rinse buffer containing prepared KHB and $40 \mathrm{mM}$ mannitol, with or without $5 \mathrm{mU} /$ $\mathrm{ml}$ insulin, for $10 \mathrm{~min}$. After rinsing, the muscle strips were transferred to incubation buffer containing prepared KHB with $1 \mathrm{mM}\left[1,2{ }^{3} \mathrm{H}\right]$-2-deoxy-glucose (Perkin Elmer, No. NET328A001MC, Boston, Mass., USA) and $39 \mathrm{~mm}\left[\mathrm{U}_{-}{ }^{14} \mathrm{C}\right]$-mannitol (Sigma Aldrich, No. 304840), with or without $5 \mathrm{mU} / \mathrm{ml}$ insulin, for 20 


\section{CardioRenal Medicine}

\begin{tabular}{l|l}
\hline Cardiorenal Med 2012;2:200-210 \\
\hline DOI: 10.1159/000339563 & $\begin{array}{l}\text { @ } 2012 \text { S. Karger AG, Basel } \\
\text { www.karger.com/crm }\end{array}$ \\
\hline Published online: July 7,2012
\end{tabular}

Manrique et al.: Loss of Estrogen Receptor a Signaling Leads to Insulin Resistance and Obesity in Young and Adult Female Mice

$\min$. The soleus was then blotted on filter paper, trimmed of tendons, frozen with liquid nitrogen, weighed, and dissolved in $0.5 \mathrm{~N} \mathrm{NaOH}$ in a $55^{\circ} \mathrm{C}$ bath. Scintillation liquid was added and samples were allowed to sit overnight. Radioactivity was measured as 2 -DOG uptake/pmol/mg/20 min by counting ${ }^{14} \mathrm{C}$ and ${ }^{3} \mathrm{H}$ disintegrations per minute simultaneously and correcting for muscle weight.

Insulin Signaling

Western Blot Analysis

Western blot analyses were performed for quantification of protein kinase B (Akt) (serine 473), and total Akt (all: Cell Signaling Technology, Inc., Beverly, Mass., USA). Briefly, mouse gastrocnemius muscles were excised and homogenized in buffer containing $250 \mathrm{mM}$ sucrose, $50 \mathrm{mM}$ HEPES, $0.5 \mathrm{mM}$ EDTA, 1 protease inhibitor cocktail tablet (Roche Applied Science, No. 05056489001, Indianapolis, Ind., USA), 200 $\mathrm{mM}$ sodium orthovanadate, and $50 \mathrm{~mm}$ sodium pyrophosphate. The homogenates were then centrifuged at $2,500 \mathrm{~g}$ at $4^{\circ} \mathrm{C}$ for $10 \mathrm{~min}$, pellets discarded, and supernatant saved as whole fraction. Protein concentration was quantified via bicinchoninic acid protein assay (Thermo Scientific, No. 23225, Rockford, Ill., USA). Whole fractions ( $30 \mu \mathrm{g} / \mathrm{lane}$ ) were separated by SDS-PAGE and transferred to nitrocellulose (BioRad Laboratories). The blots were blocked with $5 \%$ bovine serum albumin (BSA) in TBS-T (Tris-buffered saline with $1 \%$ Tween-20) at room temperature, then incubated $1 \mathrm{~h}$ at room temperature with primary antibodies (1:1,000 dilution) in 5\% BSA, rinsed with TBS-T and incubated with horseradish peroxidaseconjugated secondary antibodies (1:30,000 dilution) in 5\% BSA for $1 \mathrm{~h}$ at room temperature. The binding of the antibodies was detected by chemiluminescence (SuperSignal West Femto), and images were recorded using a Bio-Rad ChemiDoc XRS image analysis system. Quantitation of protein band density was performed using Image Lab software (Bio-Rad). Data are reported as the normalized protein band density in arbitrary units.

Immunoprecipitation

Mouse gastrocnemius whole fraction was obtained as described above. $600 \mu \mathrm{g}$ of protein was added to immunoprecipitation (IP) buffer containing $20 \mathrm{~mm}$ tris- $\mathrm{HCl} \mathrm{pH} \mathrm{8.0,137} \mathrm{mM} \mathrm{NaCl,} 10 \%$ glycerol, $1 \%$ Nonidet P-40, $2 \mathrm{~mm}$ EDTA, and protease inhibitor cocktail tablet to a total volume of $0.2 \mathrm{ml}$. Antibody, either phosphatidylinositol 3-kinase (PI3K) p85 rabbit (Cell Signaling Technology, No. 4257, Danvers, Mass., USA) or insulin receptor substrate-1 (IRS-1) rabbit (Cell Signaling Technology, No. 2382, Danvers, Mass., USA), were added to the lysates at 1:50 dilution. Lysates were then incubated with agitation at $4^{\circ} \mathrm{C}$ overnight. $70 \mu \mathrm{l}$ of washed protein A/G plus-agarose beads (Santa Cruz Biotechnology, No. sc-2003, Santa Cruz, Calif., USA) were added to cell lysates and incubated $4 \mathrm{~h}$ with agitation at $4^{\circ} \mathrm{C}$. Then lysates were pelleted, supernatant removed, and beads were washed with IP buffer 5 times. $45 \mu \mathrm{l}$ of Laemmli sample buffer (Bio-Rad Laboratories, No. 161-0737, Hercules, Calif., USA) was added to beads and the slurry was heated at $100^{\circ} \mathrm{C}$ for $5 \mathrm{~min}$. The beads were once more pelleted and supernatant loaded onto 4-20\% SDS-PAGE gels and run until dye front reached bottom of the gel. Protein was transferred onto nitrocellulose membranes overnight at $4^{\circ} \mathrm{C}$ at $30 \mathrm{~V}$. After $1 \mathrm{~h}$ blocking in $5 \% \mathrm{BSA}$, the membranes were probed with antibody, either PI3K p 85 mouse (Abcam, Cambridge, Mass., USA) or IRS-1 mouse (Cell Signaling, No. 3194S, Danvers, Mass., USA) in 5\% BSA, for $1 \mathrm{~h}$ at room temperature. After rinsing, the membranes were probed with anti-mouse secondary antibody (Jackson ImmunoResearch Laboratories) in 5\% BSA for $1 \mathrm{~h}$. After washing, SuperSignal West Femto was used to resolve the bands.

\section{3-Nitrotyrosine Immunostaining}

3-Nitrotyrosine (3-NT) was quantified as previously described [14]. Samples were incubated with 1: 150 primary rabbit polyclonal anti-nitrotyrosine antibody overnight (Chemicon, Temecula, Calif., USA). Sections were then washed and incubated with secondary antibodies, linked, and labeled with streptavidin for $30 \mathrm{~min}$ each. After several rinses with distilled water, diaminobenzidine was applied for $10 \mathrm{~min}$, sections again rinsed and stained with hematoxylin for $30 \mathrm{~s}$, rehydrated, and mounted with a permanent medium. The slides were inspected under a bright-field (50i; Nikon) microscope and the $\times 40$ images were captured with a cool snapcf camera and intensities measured with MetaView [14]. 


\section{CardioRenal Medicine}

\begin{tabular}{l|l}
\hline Cardiorenal Med 2012;2:200-210 \\
\hline DOI: 10.1159/000339563 & $\begin{array}{l}\text { @ 2012 S. Karger AG, Basel } \\
\text { www.karger.com/crm }\end{array}$ \\
Published online: July 7, 2012
\end{tabular}

Manrique et al.: Loss of Estrogen Receptor $\alpha$ Signaling Leads to Insulin Resistance and Obesity in Young and Adult Female Mice

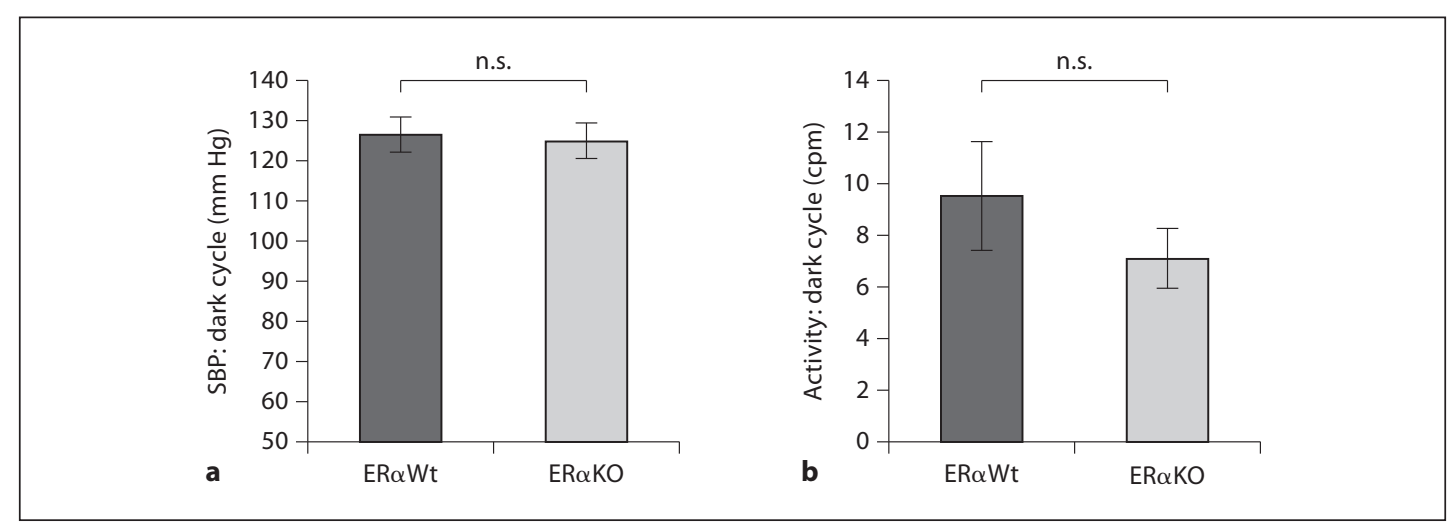

Fig. 1. Lack of estrogen signaling through ER $\alpha$ did not result in differences in SBP or spontaneous cage activity. a SBP assessed by telemetry was not different in the 30-week-old ER $\alpha \mathrm{KO}$ mice when compared with ER $\alpha \mathrm{Wt}$. b Spontaneous cage activity was not significantly different within the different cohorts at 30 weeks of age. $E R \alpha K O: n=6, E R \alpha W t: n=5$. n.s. = Not significant.

Table 1. Body weight in grams (g) at the time of sacrifice

\begin{tabular}{lcc}
\hline & ER $\alpha$ KO & ER $\alpha$ Wt \\
\hline 14 weeks & $22 \pm 0.9 \mathrm{~g}^{*}$ & $19 \pm 0.4 \mathrm{~g}$ \\
30 weeks & $21.18 \pm 0.21 \mathrm{~g}^{*}$ & $25.41 \pm 0.27 \mathrm{~g}$ \\
\hline${ }^{*} \mathrm{p}<0.05$ compared with controls. & \\
\hline
\end{tabular}




\section{CardioRenal Medicine}

\begin{tabular}{l|l}
\hline Cardiorenal Med 2012;2:200-210 \\
\hline DOI: $10.1159 / 000339563$ \\
Published online: July 7, 2012 & $\begin{array}{l}\text { ( ) 2012 S. Karger AG, Basel } \\
\text { www.karger.com/crm }\end{array}$ \\
\hline
\end{tabular}



Fig. 2. Whole-body insulin sensitivity declines with aging in the $E R \alpha K O$ model. a Insulin sensitivity assessed by IPGTT with an injection of dextrose $(0.75 \mathrm{~g} / \mathrm{kg})$ was not significantly different in the 14-weekold cohorts after a 5 -hour fast. AUC of glycemic excursion is depicted in the figure. Glucose was examined at $0,15,30,45,60$ and $120 \mathrm{~min}$. ER $\alpha \mathrm{KO}: \mathrm{n}=7, \mathrm{ER} \alpha \mathrm{Wt}: \mathrm{n}=8$. b AUC was significantly increased in the $\mathrm{ER} \alpha \mathrm{KO}$ when compared with the ER $\alpha \mathrm{Wt}$ cohort. ER $\alpha \mathrm{KO}: \mathrm{n}=10, \mathrm{ER} \alpha \mathrm{Wt}: \mathrm{n}=11 .{ }^{*} \mathrm{p}<0.05$.

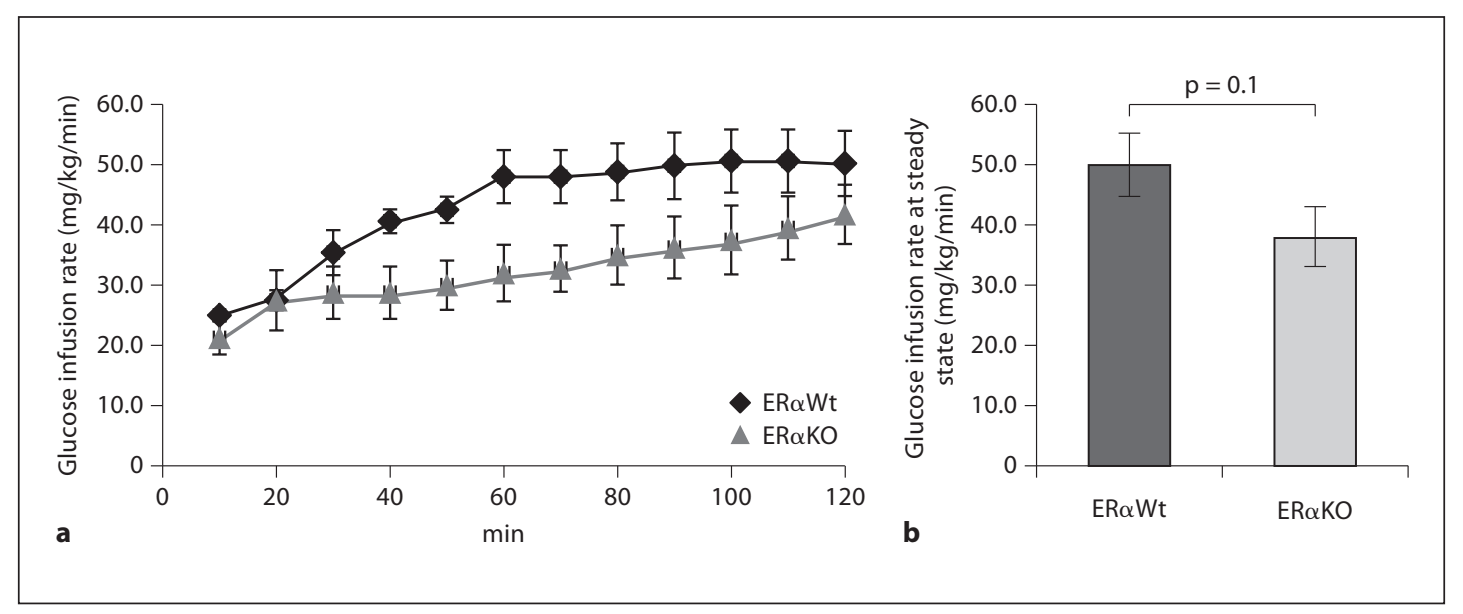

Fig. 3. a Glucose infusion rate during the euglycemic-hyperinsulinemic clamp at 18 weeks of age. Steady state was reached during the last $40 \mathrm{~min}$ of the clamp. b Glucose infusion rate at steady state (80-120 min) was lower in the ER $\alpha \mathrm{KO}$ cohort when compared to the ER $\alpha \mathrm{Wt}$ cohort, although the difference did not reach statistical significance. $\mathrm{ER} \alpha \mathrm{KO}: \mathrm{n}=4, \mathrm{ER} \alpha \mathrm{Wt}: \mathrm{n}=6$.

lenge was 33,384 \pm 3,055 in ER $\alpha W t$ versus 43,705 $\pm 6,270$ in $\mathrm{ER} \alpha \mathrm{KO}$ mice ( $\mathrm{p}=0.1$; fig. 2a). In 30 -week-old mice, the AUC was significantly different between the different cohorts: 53,628 $\pm 2,400$ in ER $\alpha W t$ versus $61,308 \pm 2,648$ in $\mathrm{ER} \alpha \mathrm{KO}$ mice ( $\mathrm{p}<0.05$; fig. $2 \mathrm{~b}$ ). In addition, the euglycemic-hyperinsulinemic clamp was employed to directly evaluate insulin sensitivity in 18-week-old mice, where we also found a trend toward decreased insulin sensitivity in $\mathrm{ER} \alpha \mathrm{KO}$ mice ( $\mathrm{p}=0.1$; fig. $3 \mathrm{a}, \mathrm{b}$ ). Collectively, these data are suggestive of age-related reduction in insulin sensitivity and impaired whole-body glucose homeostasis in $\mathrm{ER} \alpha \mathrm{KO}$ mice.

We further investigated insulin sensitivity specifically in skeletal muscle tissue, which is responsible for more than $75 \%$ of insulin-mediated glucose transport [15]. We evaluated insulin-stimulated 2-DOG uptake in soleus skeletal muscle in these rodents. In the 14-week- 


\section{CardioRenal Medicine}

\begin{tabular}{l|l}
\hline Cardiorenal Med 2012;2:200-210 \\
\hline DOI: $10.1159 / 000339563$ \\
Published online: July 7, 2012 & $\begin{array}{l}\text { ( ) 2012 S. Karger AG, Basel } \\
\text { www.karger.com/crm }\end{array}$ \\
\hline
\end{tabular}

Manrique et al.: Loss of Estrogen Receptor $\alpha$ Signaling Leads to Insulin Resistance and Obesity in Young and Adult Female Mice

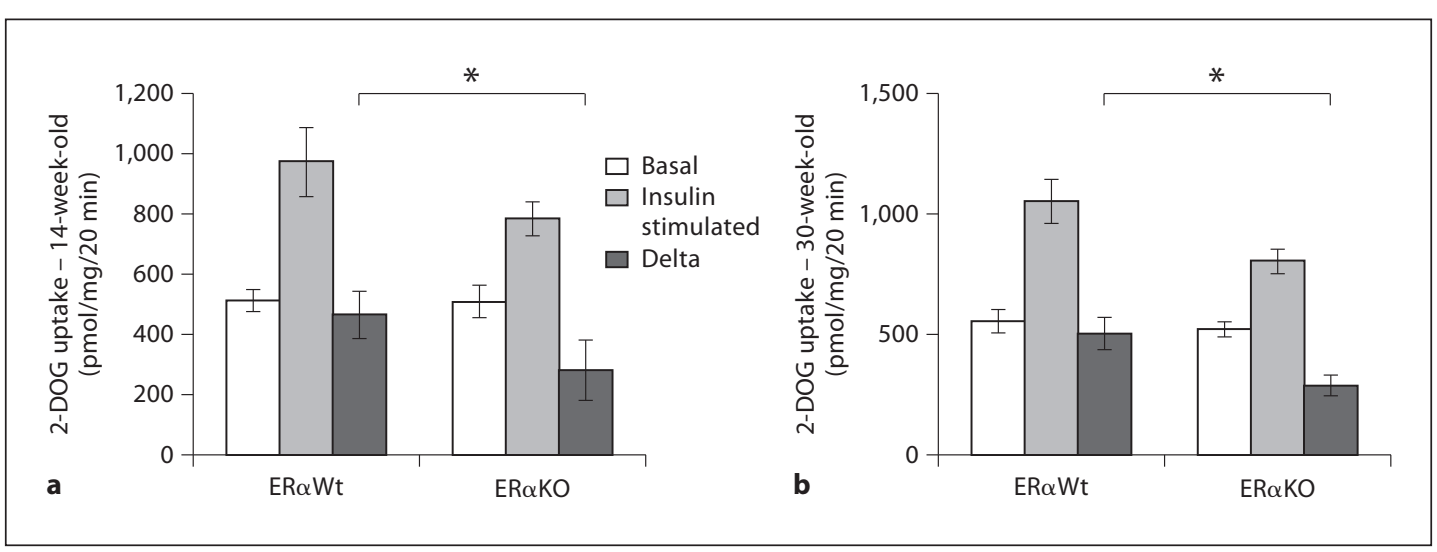

Fig. 4. Insulin-stimulated 2-DOG uptake was decreased in ER $\alpha \mathrm{KO}$ mice at 14 and 30 weeks of age. a In 14-week-old ER $\alpha$ KO mice, 2-DOG uptake was significantly decreased when compared with ER $\alpha \mathrm{Wt}$ littermate controls. $\mathrm{ER} \alpha \mathrm{KO}: \mathrm{n}=7, \mathrm{ER} \alpha \mathrm{Wt}: \mathrm{n}=6$. $\mathbf{b}$ The 30 -week-old $\mathrm{ER} \alpha \mathrm{KO}$ cohort also displays decreased 2-DOG uptake in soleus muscle when compared with ER $\alpha \mathrm{Wt}$ controls. ER $\alpha \mathrm{KO}: \mathrm{n}=9, \mathrm{ER} \alpha \mathrm{Wt}: \mathrm{n}=9$. ${ }^{*} \mathrm{p}<0.05$.

old mice, lack of ER $\alpha$ resulted in decreased insulin-stimulated 2-DOG uptake (465.18 \pm 78.18 and $282.11 \pm 99.01 \mathrm{pmol} / \mathrm{mg} / 20 \mathrm{~min}$ for $\mathrm{ER} \alpha \mathrm{KO}$ and $\mathrm{ER} \alpha \mathrm{Wt}$ mice, respectively; $\mathrm{p}<$ 0.05). Likewise, the 30 -week-old $\mathrm{ER} \alpha \mathrm{KO}$ cohort also demonstrated decreased insulin-stimulated 2-DOG $(287.28 \pm 42.97 \mathrm{pmol} / \mathrm{mg} / 20 \mathrm{~min}$ compared with $503.13 \pm 65.94 \mathrm{pmol} / \mathrm{mg} / 20$ min in ER $\alpha$ Wt mice; fig. 4), thus suggesting skeletal muscle as the main tissue responsible for impaired insulin sensitivity in mice lacking ER $\alpha$.

\section{Insulin Metabolic Signaling and Oxidative Stress}

We found alterations in critical steps of the metabolic signaling pathway. In gastrocnemius muscle, we examined the association of IRS-1 and PI3K subunit p85 (regulatory subunit). The activation of Akt, evidenced by the phosphorylation $(\mathrm{P})$ of the serine residue 473, was decreased in the 30-week-old $\mathrm{ER} \alpha \mathrm{KO}$ mice when compared with $\mathrm{ER} \alpha \mathrm{Wt}$ mice (fig. 5a). In concordance with the decreased (P) of Akt, there was decreased association of IRS-1/PI3K in the 30-week-old $\mathrm{ER} \alpha \mathrm{KO}$ relative to $\mathrm{ER} \alpha \mathrm{Wt}$ mice (fig. 5b).

The production of peroxynitrite with 3-NT immunostaining was evaluated in parallel with insulin metabolic signaling. We documented increased skeletal muscle 3-NT immunostaining in the ER $\alpha \mathrm{KO}$ mice, consistent with increased oxidative stress in absence of estrogen signaling through $\mathrm{ER} \alpha$ (fig. 5c).

\section{Discussion}

The present investigation demonstrates that lack of estrogen signaling through ER $\alpha$ in female mice is associated with increased body weight in concert with age-related impairments in whole-body insulin sensitivity and insulin-mediated glucose transport in skeletal muscle. These changes occurred in parallel with decreased insulin metabolic signaling and increased oxidative stress. Our data support and confirm the influence of ER $\alpha$ on both systemic and skeletal muscle insulin sensitivity, and contribute to better ascertainment of the mechanisms implicated in estrogen protection against insulin resistance, which leads to DM2 and CVD. 


\section{CardioRenal Medicine}

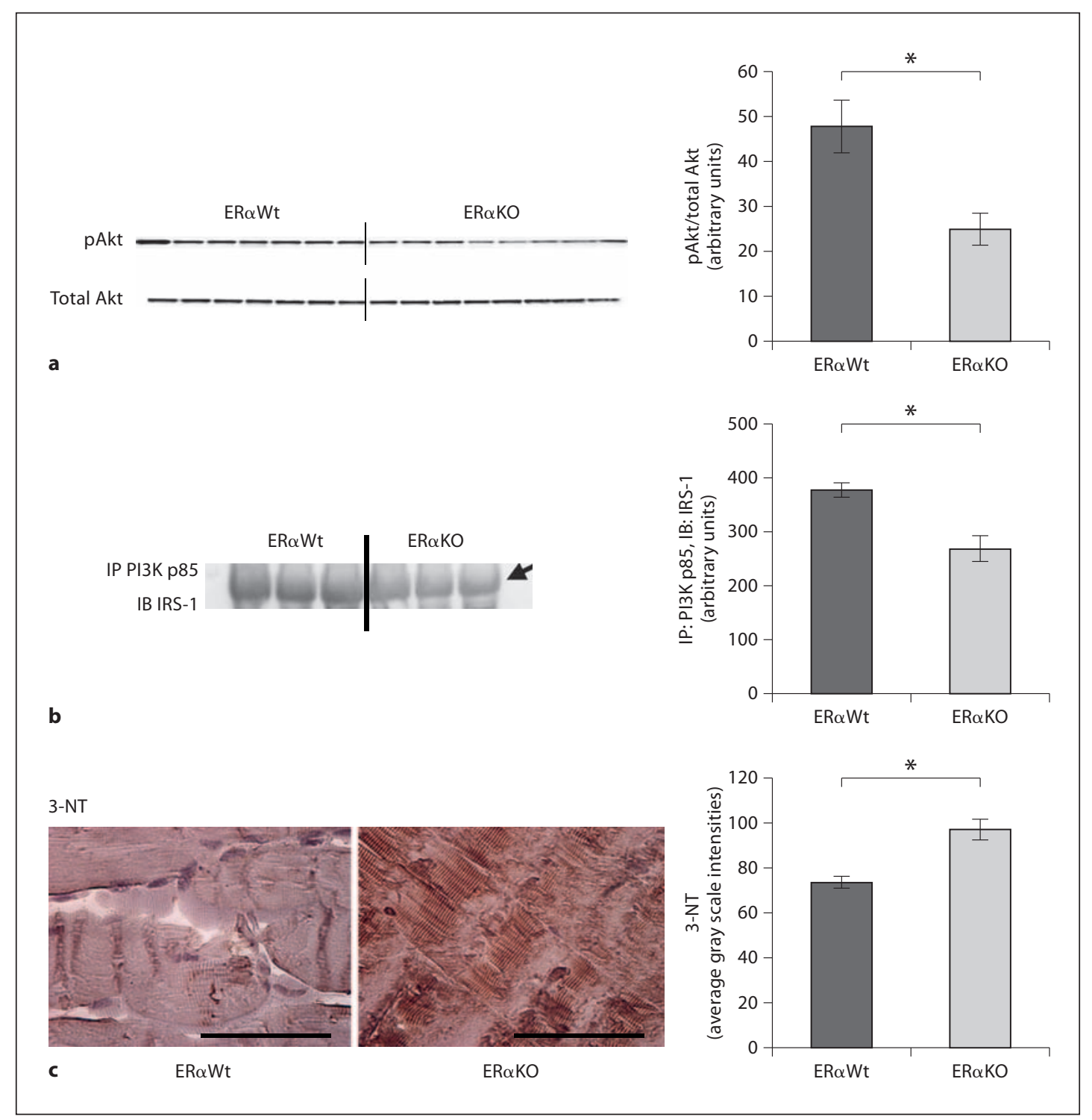

Fig. 5. Insulin metabolic signaling is impaired in gastrocnemius skeletal muscle of ER $\alpha \mathrm{KO}$ mice in concert with increased oxidative stress at 30 weeks of age. a Serine 473 (P) examined by immunoblotting (IB) and normalized to total Akt expression was significantly reduced in the ER $\alpha$ KO mice. $\mathbf{b}$ Association of PIK3 and IRS-1, examined by IP for PI3K p85 subunit and subsequent IB for total IRS-1, was significantly diminished in ER $\alpha \mathrm{KO}$ mice when compared to controls. c 3-NT immunostaining was increased in $\mathrm{ER} \alpha \mathrm{KO}$ mice when compared with ER $\alpha \mathrm{Wt}$ controls. ER $\alpha \mathrm{KO}: \mathrm{n}=5, \mathrm{ER} \alpha \mathrm{Wt}: \mathrm{n}=5 .{ }^{*} \mathrm{p}<0.05$.

Several studies have also demonstrated an important role for estrogen in insulin sensitivity and glucose homeostasis in women. In healthy post-menopausal women, insulin resistance as evaluated by the Homeostasis Model Assessment (HOMA-IR) was significantly associated in a dose-response manner with plasma levels of total estradiol and bioavailable estradiol. These associations remained significant independent of body mass index and waist to hip ratio [16]. In a large randomized controlled trial including 4,263 post-menopausal women with coronary artery disease followed for 4.1 years, hormonal replacement therapy (estrogen and progestin) was associated with a reduced incidence of DM2 by 35\% [17]. 


\section{CardioRenal Medicine}

Our data are consistent with previous studies which also have demonstrated a role for $\mathrm{ER} \alpha$ in modulating insulin resistance and body composition. Global $\mathrm{ER} \alpha \mathrm{KO}$ in mice results in reduced oxygen uptake and caloric expenditure, in concert with elevations in markers of insulin resistance and inflammation in skeletal muscle, along with impaired glucose tolerance. These abnormalities are worsened by a high-fat diet, which typically aggravates insulin resistance [18]. Supplementation of Wt ovariectomized mice with estrogen exerts a protective effect against high-fat diet-induced insulin resistance and glucose intolerance [19]. Furthermore, estrogen improves insulin metabolic signaling in skeletal muscle tissue in these animals, although this beneficial effect is blunted in ER $\alpha$-deficient mice [19]. Conversely, pharmacologic activation of $\mathrm{ER} \alpha$ with the selective ligand propylpyrazoletriyl (PPT) in young (8-10 weeks old) ovariectomized Wt rats resulted in increased insulin-stimulated glucose uptake in skeletal muscle, as well as improved insulin signaling as evaluated by Akt (P) and increased (P) of adenosine 5'-monophosphate (AMP)-activated protein kinase (AMPK) [20].

The mechanisms underlying the beneficial effects of signaling through ER $\alpha$ on insulin sensitivity remain to be fully elucidated. Insulin signaling through ER $\alpha$ in tissues other than skeletal muscle appears to play a pivotal role in the modulation of glucose homeostasis and insulin sensitivity. In ovariectomized female rats, glucose intolerance induced by high-fat diet is associated with decreased expression of $\mathrm{ER} \alpha$ and glucose transporter type 4 (GLUT4) in adipose tissue but not in skeletal muscle, in concert with activation of pro-inflammatory molecules (c-jun $\mathrm{NH}_{2}$-terminal kinase and inhibitor of $\kappa \mathrm{B}$ kinase $\beta$ ), suggesting an impact of impaired glucose homeostasis on ER $\alpha$ expression in adipose tissue [21]. Activation of ER $\alpha$ in 3T3-L1 adipose cells improves insulin-stimulated glucose uptake along with increased insulin signaling as evaluated by tyrosine (P) of IRS-1 [22].

Utilizing the euglycemic-hyperinsulinemic clamp, a defective suppression of hepatic glucose output has been demonstrated in $\mathrm{ER} \alpha \mathrm{KO}$ mice, along with increased expression of genes involved in lipid biosynthesis, and decreased expression of genes involved in lipid transport (in particular the gene encoding for the leptin receptor) [10]. Likewise, earlier studies in rats have demonstrated that estrogens increase hepatic insulin sensitivity by decreasing gluconeogenesis and glycogenolysis [23]. However, in the current study, hepatic glucose output was not different in the ER $\alpha \mathrm{KO}$ mice (data not shown), which might be related to the young age of the animals and also underscores the important role of skeletal muscle.

Our data are consistent with previous studies showing increased body weight and decreased physical activity in ER $\alpha \mathrm{KO}$ mice relative to $\mathrm{Wt}$ [18], which has a direct effect on insulin sensitivity. Not surprisingly, ER $\alpha \mathrm{KO}$ mice have increased plasma levels of leptin and decreased levels of adiponectin. Energy expenditure is reduced in the absence of ER $\alpha$ and appears to be the leading mechanism of weight gain, since food intake is similar between $\mathrm{ER} \alpha \mathrm{KO}$ animals and controls [9]. Studies in female mice have also shown that signaling through $\mathrm{ER} \alpha$ in the ventromedial nucleus of the hypothalamus plays an important role in determining food intake, insulin sensitivity, and energy expenditure [24]. The present study is focused on skeletal muscle, which is a major metabolic target of insulin and responsible for $>75 \%$ of insulin-mediated glucose transport [15]. Our data show worsening in insulin-mediated glucose transport and insulin signaling in skeletal muscle in agreement with previous reports in which activation of ER $\alpha$ resulted in increased insulin-stimulated glucose uptake in the slow-twitch soleus and fast-twitch extensor digitorum longus muscles, along with enhanced signaling through Akt and increased expression of GLUT4 [20].

Our data also support the presence of increased oxidative stress in the ER $\alpha \mathrm{KO}$ mice. Interestingly, increased oxidative stress has been postulated as a potential disruptor of insulin metabolic signaling in conditions such as obesity and the cardiorenal metabolic syndrome $[25,26]$ and might contribute to the genesis of impaired skeletal muscle and systemic insulin resistance in the absence of estrogen signaling through $\mathrm{ER} \alpha$ receptor. 


\section{CardioRenal Medicine}

Even though insulin-induced glucose uptake was impaired in the younger group of female mice, the current study clearly documented systemic impairment of glucose homeostasis in the older cohort of ER $\alpha \mathrm{KO}$ mice. The lack of overt hyperglycemia in the younger cohort might be explained by the progressive and steady decline of $\beta$ cell function which was not evaluated in our study. Finally, glucose metabolism in skeletal muscle is closely related to skeletal muscle blood flow, which is enhanced by endothelial production of nitric oxide (NO) via activation of endothelial NO synthase (eNOS) [27]. Under normal conditions, insulin stimulates NO production to increase microvascular perfusion [27]. In contrast, under insulin-resistant conditions, the ability of insulin to activate eNOS is impaired, thereby compromising tissue blood flow [28, 29], and the bioavailability of NO is reduced as a result of the oxidative stress that accompanies insulin resistance [30]. Estrogen promotes endotheliumdependent vasodilation resulting in improved microcirculation in insulin-sensitive tissues, such as skeletal muscle, and enhanced vascular actions of insulin microcirculation. The present study was not designed to address the skeletal muscle vasculature and further studies in this area are warranted.

The present paper adds to current knowledge about impact of estrogen signaling through $\mathrm{ER} \alpha$, as it explores insulin sensitivity in skeletal muscle in both young and mature rodents lacking this receptor. Our data reveal age-related impairments in whole-body insulin sensitivity in $\mathrm{ER} \alpha \mathrm{KO}$ mice, which we have in turn localized to defects in metabolic insulin signaling and glucose transport specifically in skeletal muscle.

In summary, our data demonstrate a critical role for estrogen signaling through ER $\alpha$ in skeletal muscle on skeletal-muscle insulin signaling and glucose disposal as well as wholebody insulin sensitivity in both young and mature female mice. Therefore, ER $\alpha$ activation is likely to explain the protection against insulin resistance and CVD in premenopausal women. Furthermore, the current investigation confirms and expands current knowledge of the impact of estrogen on insulin sensitivity and has potential translational implications for the prevention and management of DM2 and CVD in women, who lose the protection afforded by female sex hormones if they develop diabetes [31].

\section{Acknowledgements}

This research was supported by the National Institutes of Health (R01-HL73101 and R01-HL1079100), Veterans Affairs Merit System 0018 (J.R.S.) and the Diabetes Cosmopolitan Foundation (C.M.).

\section{Disclosure Statement}

The authors have no conflicts of interest.

\section{References}

1 Flegal KM, Carroll MD, Ogden CL, Curtin LR: Prevalence and trends in obesity among US adults, 1999-2008. JAMA 2010;303:235-241.

2 Flegal KM, Carroll MD, Kit BK, Ogden CL: Prevalence of obesity and trends in the distribution of body mass index among US adults, 1999-2010. JAMA 2012;307:491-497.

-3 Ford ES: Risks for all-cause mortality, cardiovascular disease, and diabetes associated with the metabolic syndrome. Diabetes Care 2005;28:1769-1778.

4 Barrett-Connor E, Giardina EGV, Gitt AK, Gudat U, Steinberg HO, Tschoepe D: Women and heart disease: the role of diabetes and hyperglycemia. Arch Intern Med 2004;164:934-942.

5 Shi H, Clegg DJ: Sex differences in the regulation of body weight. Physiol Behav 2009;97:199-204. 


\section{CardioRenal Medicine}

\begin{tabular}{l|l}
\hline Cardiorenal Med 2012;2:200-210 \\
\hline DOI: $10.1159 / 000339563$ \\
Published online: July 7, 2012 & $\begin{array}{l}\text { @ 2012 S. Karger AG, Basel } \\
\text { www.karger.com/crm }\end{array}$ \\
\hline
\end{tabular}

Manrique et al.: Loss of Estrogen Receptor $\alpha$ Signaling Leads to Insulin Resistance and Obesity in Young and Adult Female Mice

6 Barros Rodrigo PA, Gustafsson JÅ: Estrogen receptors and the metabolic network. Cell Metab 2011;14:289-299.

7 Jones ME, Thorburn AW, Britt KL, Hewitt KN, Wreford NG, Proietto J, Oz OK, Leury BJ, Robertson KM, Yao S, Simpson ER: Aromatase-deficient (ArKO) mice have a phenotype of increased adiposity. Proc Natl Acad Sci USA 2000;97: 12735-12740.

8 Meyer MR, Clegg DJ, Prossnitz ER, Barton M: Obesity, insulin resistance and diabetes: sex differences and role of oestrogen receptors. Acta Physiol 2011;203:259-269.

$\checkmark 9$ Heine PA, Taylor JA, Iwamoto GA, Lubahn DB, Cooke PS: Increased adipose tissue in male and female estrogen receptor- $\alpha$ knockout mice. Proc Natl Acad Sci USA 2000;97:12729-12734.

-10 Bryzgalova G, Gao H, Ahren B, Zierath JR, Galuska D, Steiler TL, Dahlman-Wright K, Nilsson S, Gustafsson JA, Efendic S, Khan A: Evidence that oestrogen receptor-alpha plays an important role in the regulation of glucose homeostasis in mice: insulin sensitivity in the liver. Diabetologia 2006;49:588-597.

-11 Foryst-Ludwig A, Clemenz M, Hohmann S, Hartge M, Sprang C, Frost N, Krikov M, Bhanot S, Barros R, Morani A, Gustafsson JA, Unger T, Kintscher U: Metabolic actions of estrogen receptor beta (ERbeta) are mediated by a negative cross-talk with PPARgamma. PLoS Genet 2008;4:e1000108.

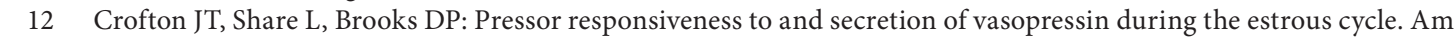
J Physiol Regul Integr Comp Physiol 1988;255:R1041-R1048.

13 Ayala JE, Bracy DP, McGuinness OP, Wasserman DH: Considerations in the design of hyperinsulinemic-euglycemic clamps in the conscious mouse. Diabetes 2006;55:390-397.

- 14 Lastra G, Habibi J, Whaley-Connell AT, Manrique C, Hayden MR, Rehmer J, Patel K, Ferrario C, Sowers JR: Direct renin inhibition improves systemic insulin resistance and skeletal muscle glucose transport in a transgenic rodent model of tissue renin overexpression. Endocrinology 2009;150:2561-2568.

15 Thiebaud D, Jacot E, DeFronzo RA, Maeder E, Jequier E, Felber JP: The effect of graded doses of insulin on total glucose uptake, glucose oxidation, and glucose storage in man. Diabetes 1982;31:957-963.

16 Kalish GM, Barrett-Connor E, Laughlin GA, Gulanski BI: Association of endogenous sex hormones and insulin resistance among postmenopausal women: results from the postmenopausal estrogen/progestin intervention trial. J Clin Endocrinol Metab 2003;88:1646-1652.

$\checkmark 17$ Kanaya AM, Herrington D, Vittinghoff E, Lin F, Grady D, Bittner V, Cauley JA, Barrett-Connor E; Heart and Estrogen/Progestin Replacement Study: Glycemic effects of postmenopausal hormone therapy: the heart and estrogen/ progestin replacement study: a randomized, double-blind, placebo-controlled trial. Ann Intern Med 2003;138:1-9.

$\checkmark 18$ Ribas V, Nguyen MT, Henstridge DC, Nguyen AK, Beaven SW, Watt MJ, Hevener AL: Impaired oxidative metabolism and inflammation are associated with insulin resistance in ER\{alpha\}-deficient mice. Am J Physiol Endocrinol Metab 2010;298:E304-E319.

19 Riant E, Waget A, Cogo H, Arnal J-F, Burcelin R, Gourdy P: Estrogens protect against high-fat diet-induced insulin resistance and glucose intolerance in mice. Endocrinology 2009;150:2109-2117.

20 Gorres BK, Bomhoff GL, Morris JK, Geiger PC: In vivo stimulation of oestrogen receptor increases insulin-stimulated skeletal muscle glucose uptake. J Physiol 2011;589:2041-2054.

21 Gorres BK, Bomhoff GL, Gupte AA, Geiger PC: Altered estrogen receptor expression in skeletal muscle and adipose tissue of female rats fed a high-fat diet. J Appl Physiol 2011;110:1046-1053.

22 Muraki K, Okuya S, Tanizawa Y: Estrogen receptor alpha regulates insulin sensitivity through IRS-1 tyrosine phosphorylation in mature 3T3-L1 adipocytes. Endocr J 2006;53:841-851.

23 Ahmed-Sorour H, Bailey C: Role of ovarian hormones in the long-term control of glucose homeostasis, glycogen formation and gluconeogenesis. Ann Nutr Metab 1981;25:208-212.

24 Musatov S, Chen W, Pfaff DW, Mobbs CV, Yang XJ, Clegg DJ, Kaplitt MG, Ogawa S: Silencing of estrogen receptor alpha in the ventromedial nucleus of hypothalamus leads to metabolic syndrome. Proc Natl Acad Sci USA 2007;104: 2501-2506.

-25 Lastra G, Whaley-Connell A, Manrique C, Habibi J, Gutweiler AA, Appesh L, Hayden MR, Wei Y, Ferrario C, Sowers JR: Low-dose spironolactone reduces reactive oxygen species generation and improves insulin-stimulated glucose transport in skeletal muscle in the TG(mRen2)27 rat. Am J Physiol Endocrinol Metab 2008;295:E110-E116.

26 Pillon NJ, Croze ML, Vella RE, Soulère L, Lagarde M, Soulage CO: The lipid peroxidation by-product 4-hydroxy-2nonenal (4-HNE) induces insulin resistance in skeletal muscle through both carbonyl and oxidative stress. Endocrinology 2012;153:2099-2111.

-27 Barrett EJ, Wang H, Upchurch CT, Liu Z: Insulin regulates its own delivery to skeletal muscle by feed-forward actions on the vasculature. Am J Physiol Endocrinol Metab 2011;301:E252-E263.

28 Sjostrand M, Gudbjornsdottir S, Holmang A, Lonn L, Strindberg L, Lonnroth P: Delayed transcapillary transport of insulin to muscle interstitial fluid in obese subjects. Diabetes 2002;51:2742-2748.

29 Keske MA, Clerk LH, Price WJ, Jahn LA, Barrett EJ: Obesity blunts microvascular recruitment in human forearm muscle after a mixed meal. Diabetes Care 2009;32:1672-1677.

30 Marchesi C, Ebrahimian T, Angulo O, Paradis P, Schiffrin EL: Endothelial nitric oxide synthase uncoupling and perivascular adipose oxidative stress and inflammation contribute to vascular dysfunction in a rodent model of metabolic syndrome. Hypertension 2009;54:1384-1392.

31 Sowers JR: Diabetes mellitus and cardiovascular disease in women. Arch Intern Med 1998;158:617-621. 